\title{
MINAT MAHASISWA MEMILIH MATA KULIAH STUDI KHUSUS SENI LUKIS PADA JURUSAN SENI RUPA FAKULTAS BAHASA DAN SENI UNIVERSITAS NEGERI MEDAN ANGKATAN 2014
}

\author{
Merry Manurung ${ }^{1 *}$, Sugito ${ }^{2 *}$ \\ Program Studi Pendidikan Seni Rupa, Jurusan Seni Rupa, Fakultas Bahasa dan Seni \\ Universitas Negeri Medan \\ Email: manru.merry@gmail.com
}

\begin{abstract}
ABSTRAK
Penelitian ini bertujuan untuk mengetahui gambaran minat mahasiswa memilih M.K studi khusus seni lukis pada Jurusan Seni Rupa FBS Unimed Angkatan 2014, untuk mengetahui sesuaikah minat mahasiswa memilih M.K studi khusus seni lukis pada Jurusan Seni Rupa FBS Unimed Angkatan 2014, dan untuk mengetahui hasil belajar M.K Studi Khusus Seni Lukis mahasiswa pada Jurusan Seni Rupa FBS Unimed Angkatan 2014. Sampel penelitian ini adalah mahasiswa yang memilih M.K studi khusus seni lukis angkatan 2014 berjumlah 34 orang. Teknik pengumpulan data menggunakan dokumentasi, dan angket. Analisis data menggunakan metode deskriptif kualitatif. Temuan hasil penelitian, M.K studi khusus seni lukis adalah M.K yang paling diminati sebesar 43,038\% (34 orang), seni patung 3,797\% (3 orang), seni kriya $13,924 \%$ (11 orang), fotografi $0 \%$, seni grafis komputer 39,241\% (31 orang). Mahasiswa memilih M.K studi khusus seni lukis karena keinginan sendiri sebesar 97,059\% (33 orang), memilih karena rasa simpatik pada pengajar dan karena dorongan orang tua sebesar $0 \%$, memilih karena diajak sebesar 2,941\% (1 orang). Hasil belajar M.K Studi Khusus seni lukis mahasiswa angkatan 2014 adalah sebesar 73,529\% (25 orang) nilai sangat bagus yakni nilai A, dan 17,647\% (6 orang) nilai bagus yakni nilai B, nilai C, dan D sebesar $0 \%$, dan 3 orang nilai E sebesar 8,824\%.
\end{abstract}

Kata Kunci: minat, mahasiswa, dan seni lukis.

\section{PENDAHULUAN}

Universitas Negeri Medan merupakan salah satu perguruan tinggi negeri di Indonesia yang mempunyai tujuh fakultas, salah satunya adalah Fakultas Bahasa dan Seni. Jurusan Seni Rupa adalah salah satu jurusan yang mempunyai mata kuliah studi khusus dengan pilihan antara lain: Seni Lukis,
Fotografi, Seni Patung, Seni kriya, dan Seni Grafis Komputer. Dari beberapa mata kuliah studi khusus tersebut mahasiswa seni rupa diharapkan memiliki satu keahlian. Ketika hendak memasuki perkuliahan semester IV mahasiswa jurusan seni rupa wajib memilih salah satu mata kuliah studi 
khusus yang mereka minati dan dipelajari selama tiga semester.

Mata kuliah studi khusus seni lukis merupakan salah satu studi khusus yang menjadi pilihan banyak mahasiswa. Mahasiswa memiliki pertimbanganpertimbangan tertentu sebelum memilih mata kuliah studi khusus seni lukis mahasiswa akan mempertimbangkan antara lain kemampuan dalam melukis, memadukan warna, berekspresi, ketertarikan terhadap mata kuliah, dosen, dan lain-lain. Pertimbangan setiap mahasiswa berbeda satu sama lain. Misalnya, mahasiswa mencari tahu terlebih dahulu siapa pengampu yang akan mengajar mata kuliah khusus tersebut, mahasiswa bermaksud untuk menghindari pengampu yang mereka anggap paling disegani. Ada sebagian mahasiswa yang menganggap pelajaran pada mata kuliah studi khusus seni lukis, sulit untuk diikuti dan ada yang beranggapan mudah dibandingkan dengan mata kuliah studi khusus yang lainnya, ada mahasiswa yang ikutikutan atau terpengaruh pada ajakan temannya, ada mahasiswa tidak memilih mata kuliah studi khusus seni lukis karena biayanya yang tergolong mahal, dan ada pula mahasiswa tidak memilih mata kuliah studi khusus seni lukis karena tidak percaya diri dengan kemampuan yang dimilikinya.

Dari beberapa pertimbangan pertimbangan di atas, minat mahasiswa menjadi pertimbangan yang paling berpengaruh dalam memilih mata kuliah studi khusus seni lukis. Tanpa minat, seseorang akan sulit untuk memusatkan pikiran dan kemampuannya dalam melakukan suatu aktivitas terhadap objek. Minat yang rendah membuat mahasiswa tidak menyukai materi perkuliahan sehingga mahasiswa akan merasa kesulitan menerima dan menguasai mata kuliah studi khusus seni lukis, dan begitu pula sebaliknya.

Berdasarkan latar belakang dapat diteliti masalah yang terjadi adalah nilai yang kurang baik, malas mengikuti perkuliahan, semangat yang kurang, dan kedisiplinan dalam mengikuti perkuliahan yang kurang baik. Kondisi dan ketidakwajaran inilah yang menimbulkan pertanyaan bagaimana peran minat dalam memilih mata kuliah studi khusus seni lukis maka peneliti ingin meneliti lebih lanjut sehingga akan dapat diketahui cara untuk mengatasi permasalahan tersebut.

Dari latar belakang yang sudah dijelaskan, maka dapat ditemukan beberapa masalah sebagai berikut:

1. Mahasiswa menghindari pengampu yang mereka anggap paling ditakuti.

2. Mahasiswa beranggapan pelajaran pada mata kuliah studi khusus seni lukis sulit untuk diikuti.

3. Mahasiswa ikut-ikutan atau terpengaruh pada ajakan teman untuk memilih studi khusus seni lukis.

4. Mahasiswa kurang percaya diri pada kemampuan melukisnya sehingga 
mahasiswa lebih memilih studi khusus yang lain.

5. Mahasiswa tidak memilih mata kuliah studi khusus seni lukis karena biaya yang tergolong mahal.

6. Minat yang rendah membuat mahasiswa tidak menyukai materi perkuliahan sehingga akan merasa kesulitan menerima dan menguasai mata kuliah studi khusus seni lukis dan begitu pula sebaliknya.

Berdasarkan identifikasi masalah yang peneliti anggap paling perlu mendapatkan perhatian adalah poin ke-6 yaitu minat mahasiswa memilih mata kuliah studi khusus seni lukis pada Jurusan Seni Rupa Fakultas Bahasa dan Seni Universitas Negeri Medan Angkatan 2014.

Adapun rumusan masalah dalam penelitian ini adalah sebagai berikut:

1. Bagaimanakah minat mahasiswa memilih mata kuliah studi khusus seni lukis pada Jurusan Seni Rupa Fakultas Bahasa dan Seni Universitas Negeri Medan Angkatan 2014 ?

2. Apakah sudah sesuai minat mahasiswa memilih mata kuliah studi khusus seni lukis pada Jurusan Seni Rupa Fakultas Bahasa dan Seni Universitas Negeri Medan Angkatan 2014 ?

3. Bagaimanakah hasil belajar Mata Kuliah Studi Khusus Seni Lukis mahasiswa pada Jurusan Seni Rupa Fakultas Bahasa dan Seni Universitas Negeri Medan Angkatan
2014, terkait dengan minat yang dimiliki?

Dalam penelitian ini tujuan yang ingin dicapai oleh peneliti adalah sebagai berikut:

1. Untuk mengetahui gambaran minat mahasiswa memilih mata kuliah studi khusus seni lukis pada Jurusan Seni Rupa Fakultas Bahasa dan Seni Universitas Negeri Medan Angkatan 2014.

2. Untuk mengetahui sudahkah sesuai minat mahasiswa memilih mata kuliah studi khusus seni lukis pada Jurusan Seni Rupa Fakultas Bahasa dan Seni Universitas Negeri Medan Angkatan 2014.

3. Untuk mengetahui hasil belajar Mata Kuliah Studi Khusus Seni Lukis mahasiswa pada Jurusan Seni Rupa Fakultas Bahasa dan Seni Universitas Negeri Medan Angkatan 2014, terkait dengan minat yang dimiliki.

Dari penelitian ini diharapkan dapat memberikan manfaat bagi berbagai pihak yaitu sebagai berikut:

1. Sebagai tambahan dokumentasi bagi perpustakaan Unimed.

2. Sebagai bahan referensi dan acuan bagi peneliti berikutnya yang relevan dengan topik penelitian ini.

3. Bagi mahasiswa Jurusan Seni Rupa dapat dijadikan sebagai bahan masukan yang penting dalam mengambil langkah tepat untuk memilih mata kuliah studi khusus seni lukis. 
4. Bagi peneliti sebagai sarana untuk menambah pengetahuan serta pengalaman terutama pada masalah yang berhubungan dengan minat

\section{A. Minat}

\section{Pengertian Minat Secara \\ Umum}

Khairani (2013:137), menyatakan bahwa "minat adalah gejala psikologis yang menunjukkan bahwa minat adanya pengertian subjek terhadap objek yang menjadi sasaran karena objek tersebut menarik perhatian dan menimbulkan perasaan senang sehingga cenderung kepada objek tertentu".

Pengertian minat secara umum adalah keinginan untuk melakukan sesuatu yang disukai tanpa adanya paksaan, dan keinginan tersebut timbul karena adanya dorongan oleh perasaan senang, rasa ketertarikan, gairah, dan kerelaan diri untuk melakukan sesuatu itu dengan baik.

\section{Pengertian Minat Memilih Mata Kuliah Studi Khusus Seni}

\section{Lukis}

Pengertian minat memilih mata kuliah studi khusus seni lukis adalah keinginan untuk memilih mata kuliah studi khusus seni lukis tanpa ada paksaan, dan keinginan tersebut timbul karena adanya dorongan oleh perasaan senang, rasa ketertarikan, gairah, kerelaan diri, dan dorongan untuk memilih mata kuliah studi khusus seni lukis, mengikuti mahasiswa memilih mata kuliah studi khusus seni lukis di Jurusan Seni Rupa.

\section{KLANDASAN TEORI}

perkuliahan dengan sebaik-baiknya dan akan memberikan hasil karya yang bagus, nilai yang bagus, dan prestasi yang tinggi.

\section{Faktor-Faktor yang}

Mempengaruhi Minat

a. Faktor Pendorongan dari Dalam (The Factor Inner Urge)

b. Faktor Motif Sosial (The Factor Of Social Motive)

c. Faktor Emosi (Emosional Factor.

\section{Macam-Macam Minat}

a. Minat yang Diekspresikan/ Expressed Interest

b. Minat yang Diwujudkan/ Manifest Interest

c. Minat yang Diinventariskan/ Inventoral Interest.

\section{Fungsi Minat}
a. Minat memudahkan terciptanya konsentrasi
b. Minat mencegah gangguan perhatian di luar
c. Minat memperkuat melekatnya bahan pelajaran dalam ingatan
d. Minat memperkecil kebosanan belajar dalam diri sendiri

\section{Kurikulum Seni Rupa Mata Kuliah Studi Khusus}

Manfaat dan tujuan mata kuliah studi khusus pada Jurusan Seni Rupa 
yaitu: agar mahasiswa alumni mampu mengembangkan kompetensinya di masyarakat selain menjadi tenaga pengajar tetapi juga dapat mengandalkan bidang profesi praktisi seni rupa sesuai dengan mata kuliah studi khusus yang didalaminya sehingga mampu membuka lapangan kerja sendiri, memanfaatkan keahlian dalam menciptakan karya seni yang bermutu, mengembangkan industri seni rupa, dan lain-lain.

\section{Standar Operasional Prosedur} (SOP) Pemilihan Studi Khusus

1. Hendak memasuki perkuliahan semester IV (Empat)

2. Membayar uang SPP

3. Mendapat rekomendasi dari dosen Pembimbing Akademik (PA) dan dari hasil nilai yang relevan dengan mata kuliah studi khusus yang hendak dipilih. Misalnya, untuk mengambil studi khusus seni lukis maka harus diperhatikan nilai yang diperoleh pada mata kuliah seni lukis I, dan seni lukis II dan nilai yang diperoleh adalah nilai $\mathrm{A}$. Demikian pula dengan mata kuliah studi khusus yang lain.

4. Mengisi Kartu Rencana Studi (KRS).

\section{Mata Kuliah Studi Khusus Seni Lukis}

\section{a. Studi Khusus Seni Lukis}

Mata kuliah studi khusus seni lukis merupakan mata kuliah wajib pilihan yang diberikan kepada mahasiswa Jurusan Seni Rupa, yang bertujuan untuk membentuk keterampilan dalam membuat konsep penciptaan karya lukis, memperdalam ide/gagasan dalam melukis, menambah wawasan tentang lukisan, dan keterampilan dalam mengharmonisasikan warna, dan lain-lain. Dosen-dosen yang mengajarkan studi khusus seni lukis antara lain: Dr. Agus Priyatno, M.Sn, Drs. Mangatas, M.Sn, Drs. R. Triyanto, M.Sn, dan Drs. Heru Maryono, M.Sn

Prasyarat untuk bisa mengambil mata kuliah studi khusus adalah apabila sudah lulus mata kuliah lukis I dan Lukis II dengan nilai $\mathrm{A}$, serta sudah lulus mata kuliah sketsa, gambar bentuk, anatomi, nirmana 2D, dan hendak memasuki perkuliahan semester 4 .

\section{b. Pengertian Seni Lukis}

Menurut Ellsworth (1957:16) menjelaskan bahwa:

The way to enjoy drawing and painting is to toss fear out the window ang try everything. Try 
new materials, new problem, new ways of working. Keep an experimental attitude. Do not copy others. You will paint best that which you are familiar. Yang artinya: cara untuk menikmati menggambar dan melukis adalah dengan melemparkan ketakutan

1) Naturalisme



Gambar 2.5. Lukisan Naturalisme (Sumber: Merry Manurung, 2016)

2) Realisme

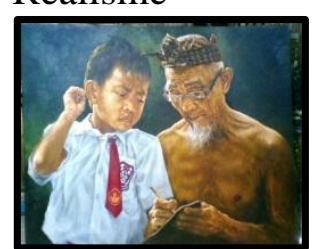

Gambar 2.6. Lukisan Realisme (Sumber: mashuripelukis.wordpress.com)

3) Romantisme

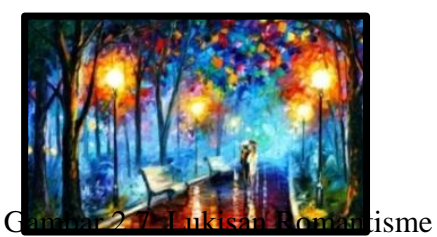

(Sumber: digaleri.com)

4) Ekpresionisme



Gambar 2.8. Lukisan Ekspresionisme (Sumber: dgi-indonesia.com)

5) Impresionisme

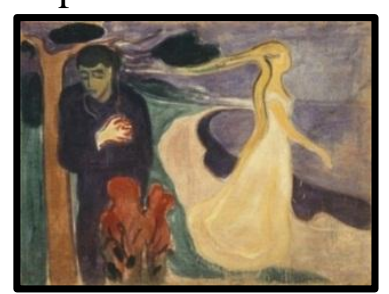

ke luar jendela dan mencoba segala sesuatu. Coba bahan-bahan baru, masalah baru, cara baru untuk bekerja. Jauhkan menyalin yang lain. Anda akan melukis dengan hasil terbaik dan Anda akan terkenal.

\section{c. Aliran-Aliran Seni Lukis}

Gambar 2.9. Lukisan Impresionisme (Sumber: cahyaarts.blogspot.co)

6) Kubisme

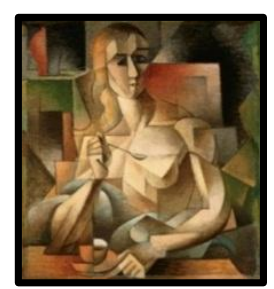

Gambar 2.10. Lukisan Kubisme (Sumber: en.wikipedia.org)

7) Dadaisme

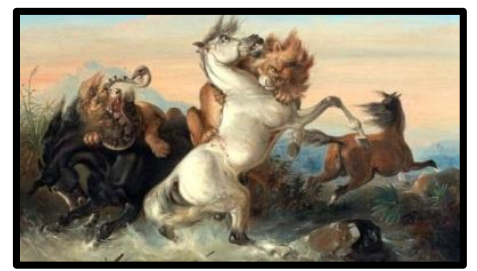

Gambar 2.11. Lukisan Dadaisme (Sumber: kunstundfilm.de)

8) Futurisme

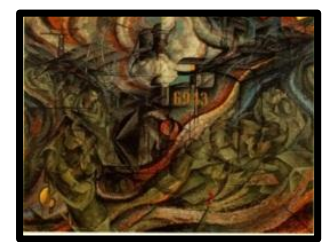

Gambar 2.12. Lukisan Futurisme (Sumber: en.wikipedia.org) 
9) Surealisme

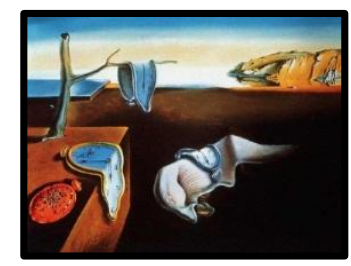

Gambar 2.13. Lukisan Surealisme

(Sumber: prasetyorestu.blogspot.com)

\section{METODE PENELITIAN}

Lokasi penelitian ini di Jurusan Seni Rupa Fakultas Bahasa dan Seni Universitas Negeri Medan. Penelitian ini bertujuan untuk mengetahui gambaran minat mahasiswa memilih mata kuliah studi khusus seni lukis pada Jurusan Seni Rupa Fakultas Bahasa dan Seni Universitas Negeri Medan Angkatan 2014, untuk mengetahui sudahkah sesuai minat mahasiswa memilih mata kuliah studi khusus seni lukis pada Jurusan Seni Rupa Fakultas Bahasa dan Seni Universitas Negeri Medan Angkatan 2014, dan untuk mengetahui hasil belajar Mata Kuliah Studi Khusus Seni Lukis mahasiswa

\section{HASIL PENELITIAN}

pada Jurusan Seni Rupa Fakultas Bahasa dan Seni Universitas Negeri Medan Angkatan 2014, terkait dengan minat yang dimiliki.

Populasi dalam penelitian ini adalah mahasiswa angkatan 2014 yang memilih mata kuliah studi khusus seni lukis di Jurusan Seni yakni berjumlah 34 orang. Sampel diambil dengan mengunakan teknik total sampling. Maka sampel penelitian ini berjumlah 34 orang. Teknik pengumpulan data yang digunakan dalam penelitian ini adalah angket/kuesioner dan dokumentasi. Analisis data menggunakan analisis deskriptif kualitatif.

\section{A. Analisis Data}

\section{Temuan Data melalui Instrumen Dokumentasi}

\section{a. Data Jumlah Mahasiswa Yang Mengambil M.K Studi Khusus Angkatan 2014}

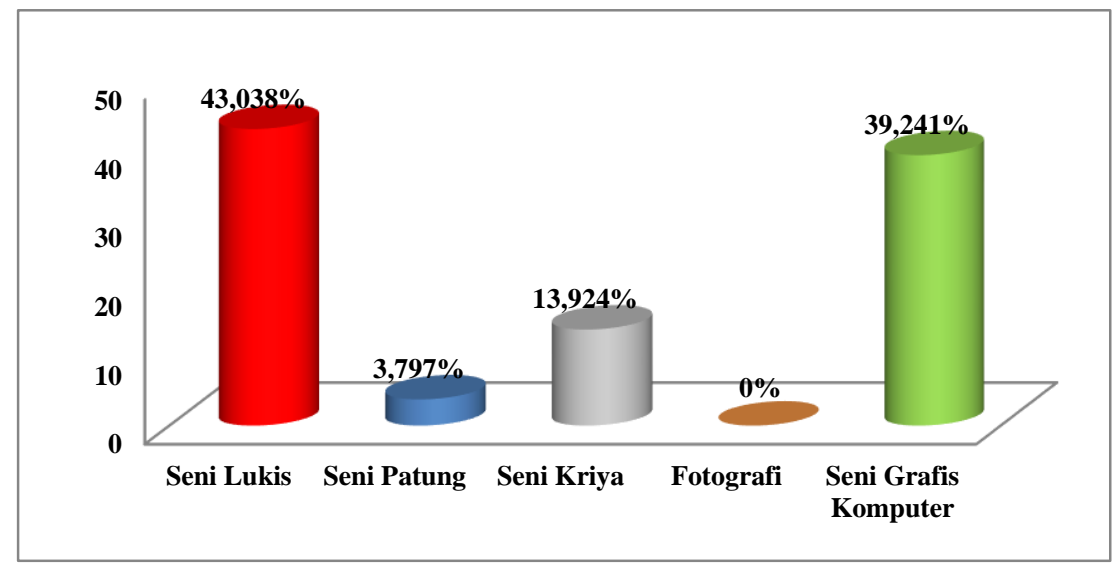

Gambar 4.1. Diagram Batang Jumlah Mahasiswa Seni Rupa yang Mengambil Mata Kuliah Studi Khusus Angkatan 2014 


\section{b. Pembelajaran Mata Kuliah Studi Khusus Seni Lukis}

Pembelajaran mata kuliah studi khusus seni lukis memberikan pemahaman dan keterampilan melukis dengan mengarah satu style (gaya), dengan media cat minyak/Aclirik di atas kanvas. Proses penciptaan melalui observasi maupun kreasi yang dilakukan diluar studio maupun di dalam studio. Materi kuliah terdiri atas: (1) Pengetahuan tentang alat bahan dan teknik cat minyak

c. Nilai Akhir Semester Ganjil 2016/2017 Jurusan Seni Rupa Angkatan 2014

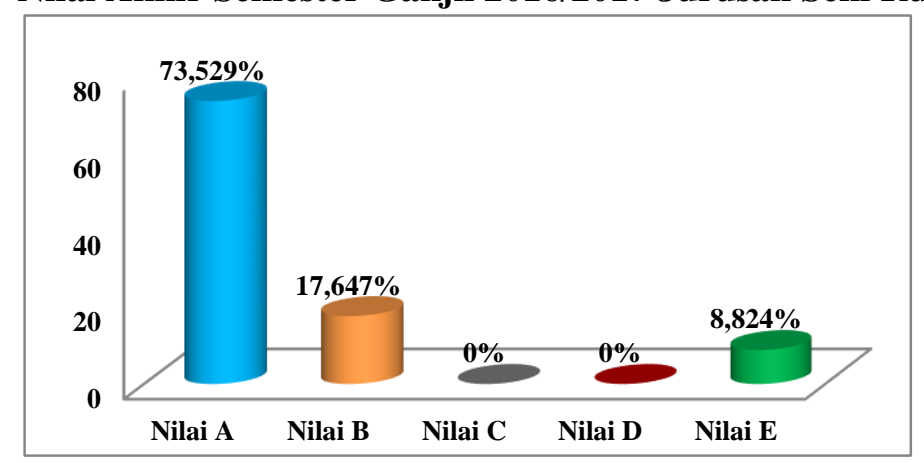

Gambar 4.6. Diagram Batang Nilai Akhir Semester Kelas A,B,C dan D

2. Temuan Data melalui Instrumen Angket

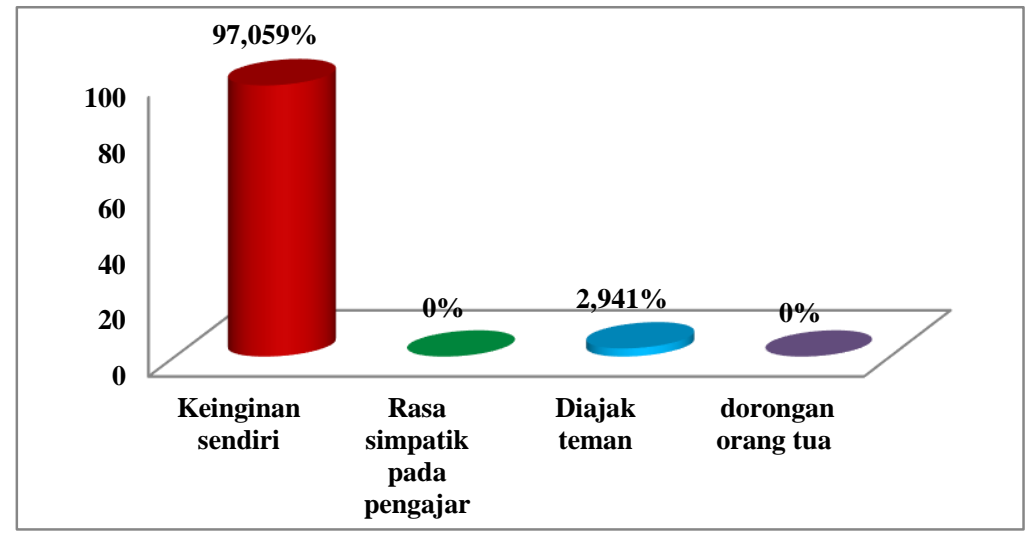

Gambar 4.7. Diagram Batang Mahasiswa Memilih M.K Studi Khusus Seni Lukis maupun cat aclirik;

Pengetauan tentang gaya/aliran seni lukis; (3) Praktek melukis sesuai dengan pikiran gaya yang disukai mahasiswa sejumlah 8 karya ukuran $70 \quad$ x $90 \quad \mathrm{~cm}$. Penilaian hasil belajar dilakukan dengan tugas praktik harian dan ujian praktik, evaluasi juga melalui pameran kelas. 




Gambar 4.7. Diagram Lingkaran Menurut Mahasiswa Pelajaran M.K Studi Khusus Seni Lukis

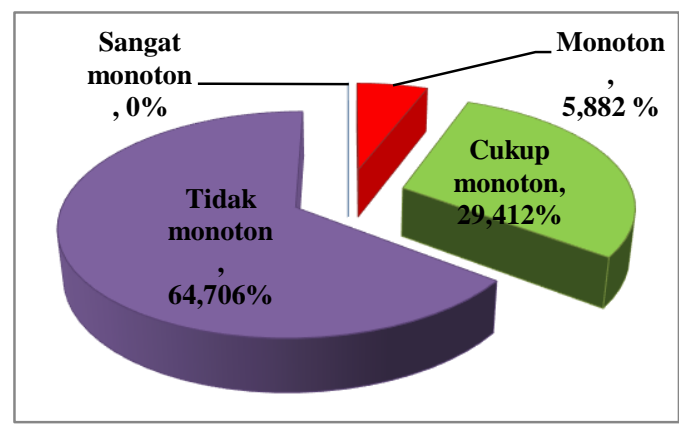

Gambar 4.8. Diagram Lingkaran Menurut Mahasiswa Pelajaran M.K Seni Lukis

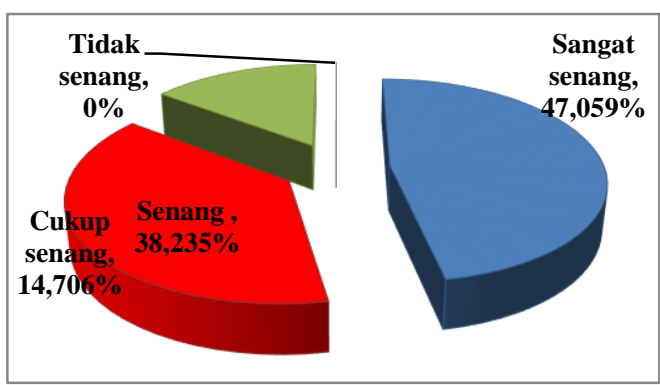

Gambar 4.9. Diagram Lingkaran Perasaan Mahasiswa Memilih M.K Studi Khusus Seni Lukis



Gambar 4.10. Diagram Lingkaran Mahasiswa Senang Melukis

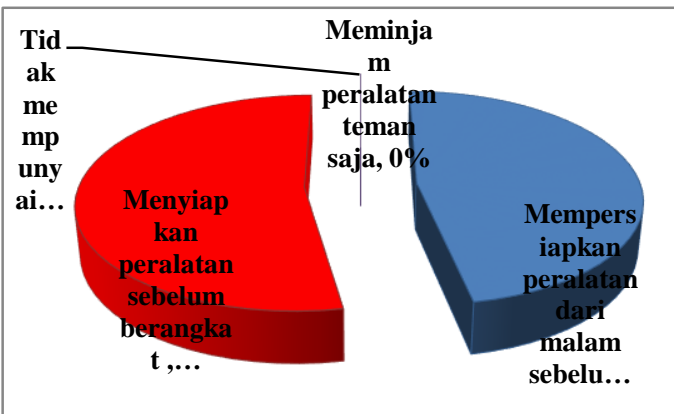

Gambar 4.11. Diagram Lingkaran Cara Mahasiswa Mempersiapkan Diri Sebelum Mengikuti Pembelajaran M.K Studi Khusus Seni Lukis

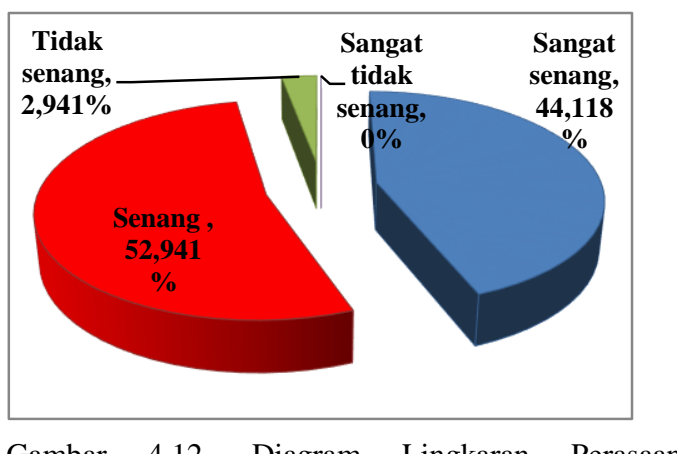

Gambar 4.12. Diagram Lingkaran Perasaan Mahasiswa Saat Mengikuti M.K Studi Khusus Seni Lukis

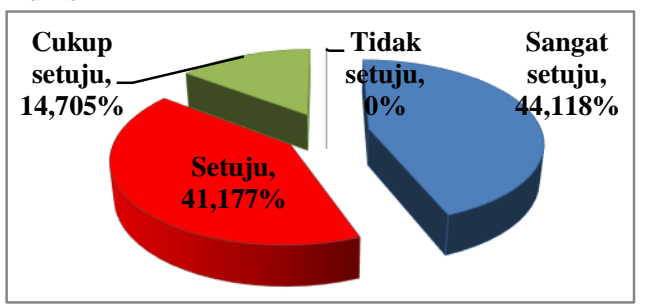


Gambar 4.13. Diagram Lingkaran Mahasiswa Memilih M.K Studi Khusus Seni Lukis Karena Pelajarannya Sangat Menarik

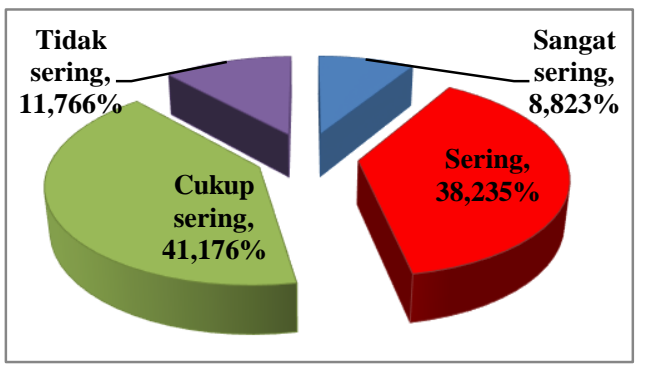

Gambar 4.14. Diagram Lingkaran Mahasiswa Sering Belajar Seni Lukis Sebelum Memilih M.K Studi Khusus Seni Lukis

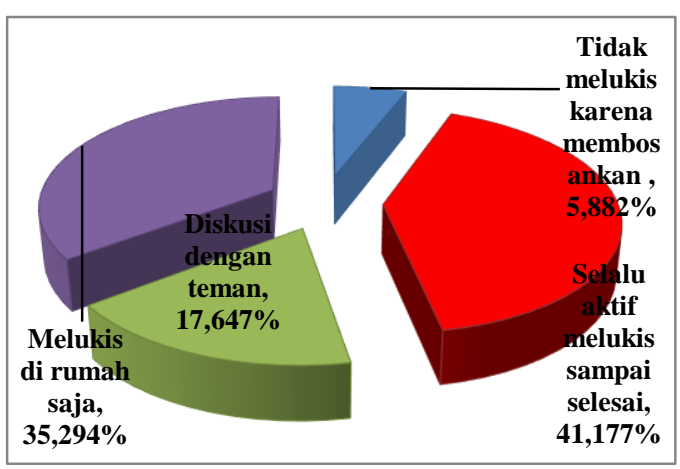

Gambar 4.15. Diagram Lingkaran Sikap Mahasiswa Saat M.K Studi Khusus Seni Lukis Berlangsung

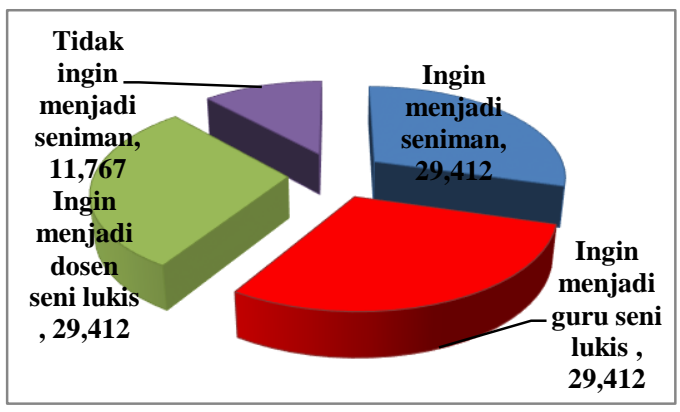

Gambar 4.16. Diagram Lingkaran Mahasiswa Memilih M.K Studi Khusus Seni Lukis

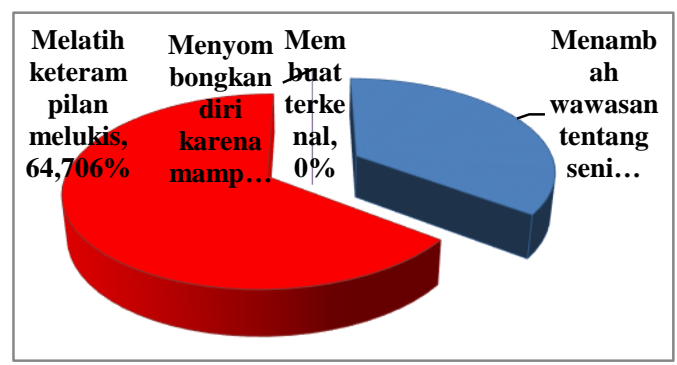

Gambar 4.17. Diagram Lingkaran Manfaat Melukis Bagi Mahasiswa

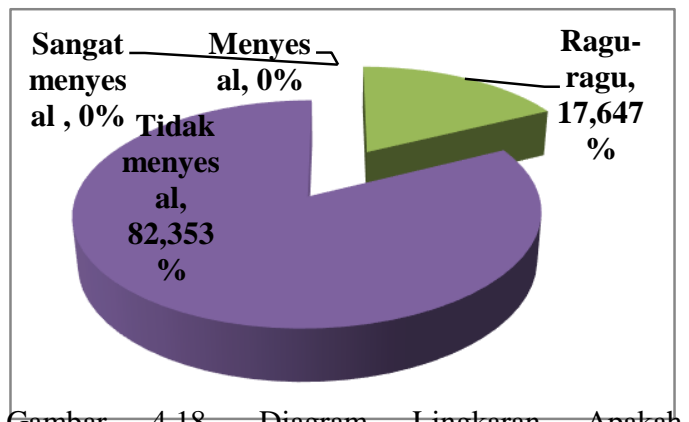

Gambar 4.18. Diagram Lingkaran Apakah Mahasiswa Menyesal Memilih M.K Studi Khusus Seni Lukis

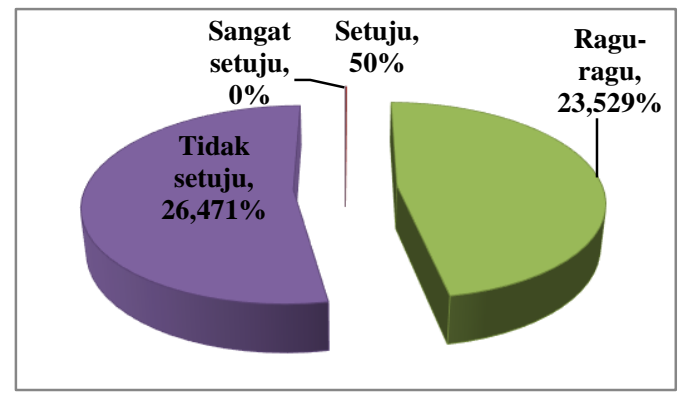

Gambar 4.19. Diagram Lingkaran Saya Tidak SeganSegan Mengerjakan Tugas M.K Seni Lukis Saya Terlebih Dahulu daripada Tugas dari M.K Lain

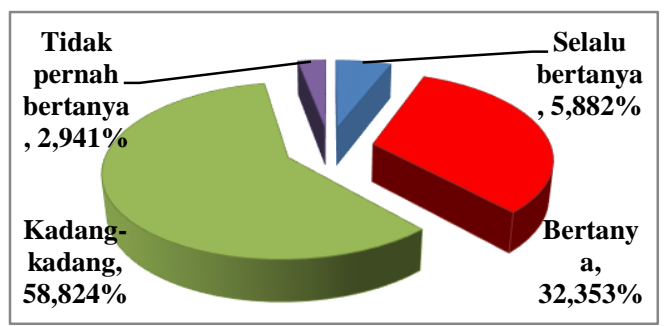

Gambar 4.20. Diagram Lingkaran Mahasiswa Bertanya Saat Penjelasan Dosen dalam Pembelajaran M.K Studi Khusus Seni Lukis Kurang/Tidak dapat Dipahami

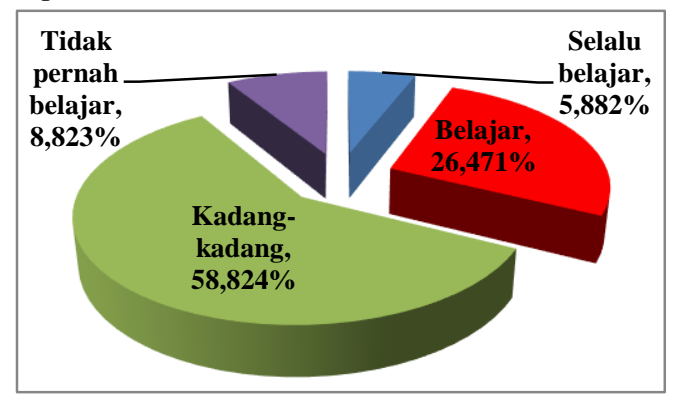


Gambar 4.21. Diagram Lingkaran Mahasiswa Belajar di Rumah Sebelum Mengikuti Pembelajaran M.K Studi Khusus Seni Lukis

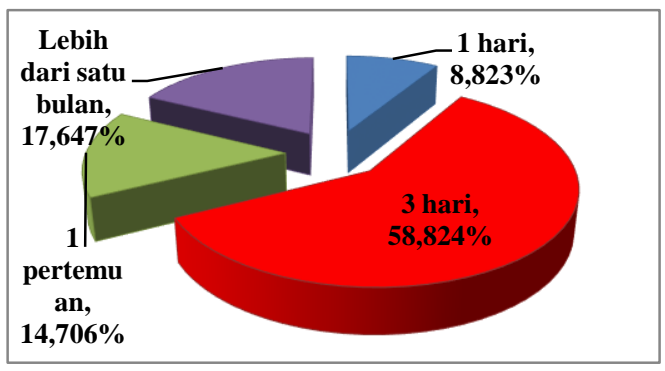

Gambar 4.22. Diagram Lingkaran Waktu yang Dibutuhkan Mahasiswa Menyelesaikan Satu Lukisan.

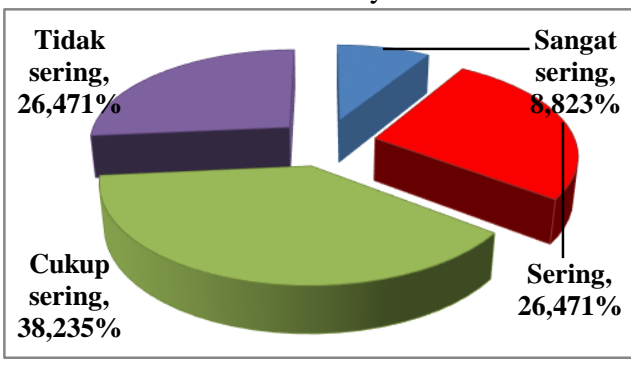

Gambar 4.23. Diagram Lingkaran Mahasiswa Sering Membuat Lukisan Selain Tugas M.K Studi Khusus Seni Lukis

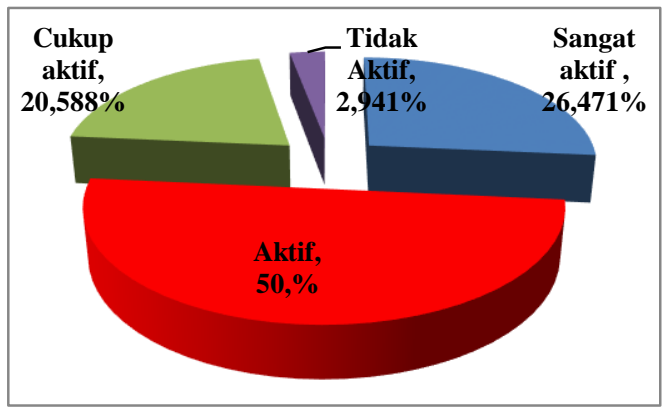

Gambar 4.24. Diagram Lingkaran Mahasiswa Aktif Mengikuti Perkuliahan M.K Studi Khusus Seni Lukis Sesuai Jadwal

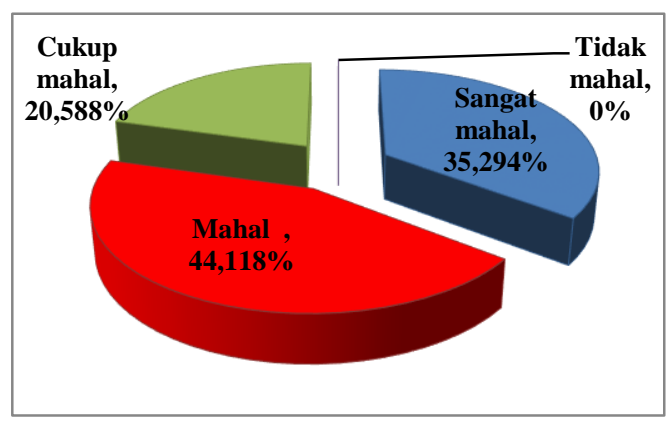

Gambar 4.25. Diagram Lingkaran Memilih M.K Studi Khusus Seni Lukis Memerlukan Biaya yang Tergolong Mahal

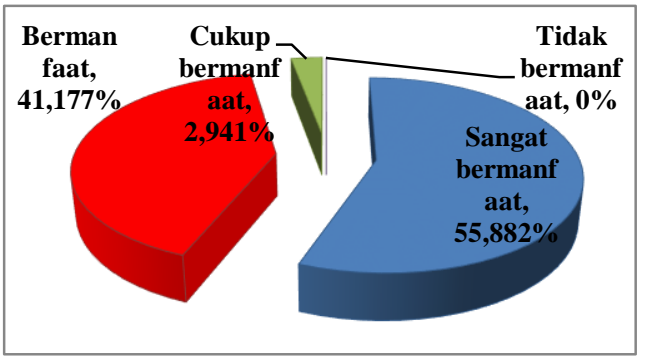

Gambar 4.26. Diagram Lingkaran Materi yang Diajarkan dalam Pembelajaran M.K Studi Khusus Seni Lukis Bermanfaat

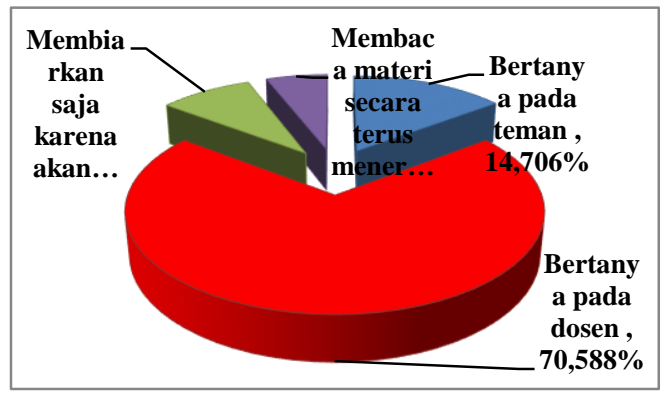

Gambar 4.27. Diagram Lingkaran Sikap Mahasiswa Ketika Tidak Paham Materi M.K Studi Khusus Seni Lukis yang Diajarkan

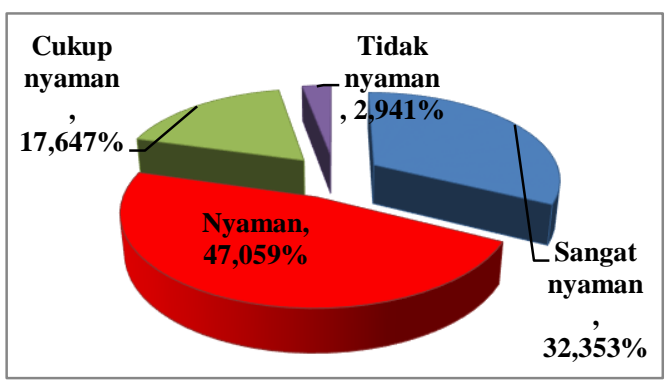

Gambar 4.28. Diagram Lingkaran Mahasiswa Nyaman Belajar M.K Studi Khusus Seni Lukis

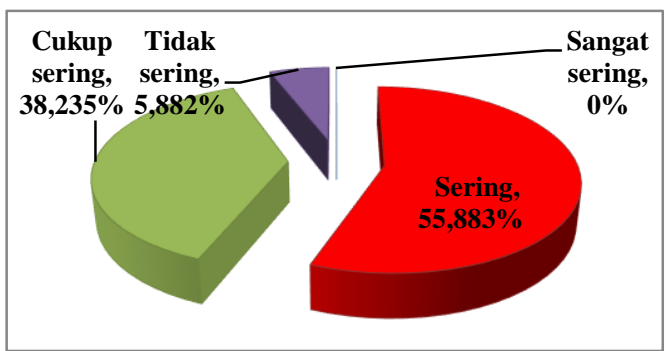


Gambar 4.29. Diagram Lingkaran Mahasiswa Sering MelukiS

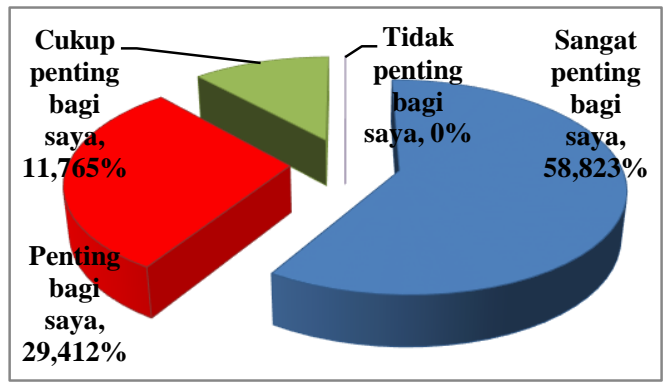

Gambar 4.30. Diagram Lingkaran Menyelesaikan Lukisan dengan Hasil yang Bagus

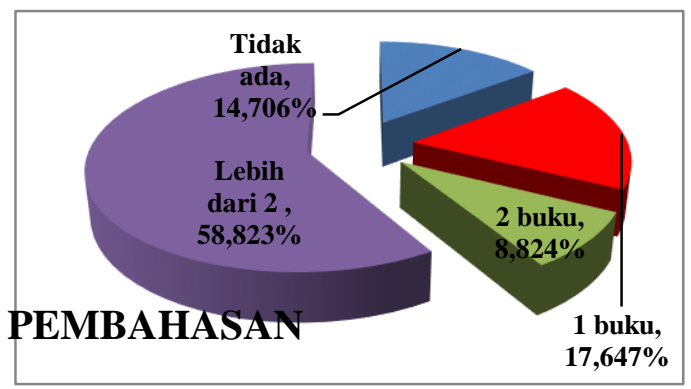

Dari temuan penelitian, diketahui bahwa sebagian besar mahasiswa Jurusan Seni Rupa Fakultas Bahasa dan Seni Universitas Negeri Medan angkatan 2014 memilih mata kuliah studi khusus seni lukis didorong oleh faktor minatnya sendiri tanpa ada paksaan dari pihak manapun untuk memilih. Hal ini berarti bahwa pengaruh luar seperti orang tua, di ajak teman, dan karena simpatik pada dosen pengajar tidak dominan atau sangat kecil. Hal tersebut terbukti dari hasil persentasenya sebesar $97,059 \% \quad(33$ orang) memilih karena keinginan sendiri, sedangkan mahasiswa memilih mata kulih studi khusus seni lukis karena diajak teman hanya berjumlah satu orang dengan persentase 2,941\%.
Gambar 4.31. Diagram Lingkaran Jumlah Buku Tentang Seni Lukis yang Sudah Mahasiswa Punya

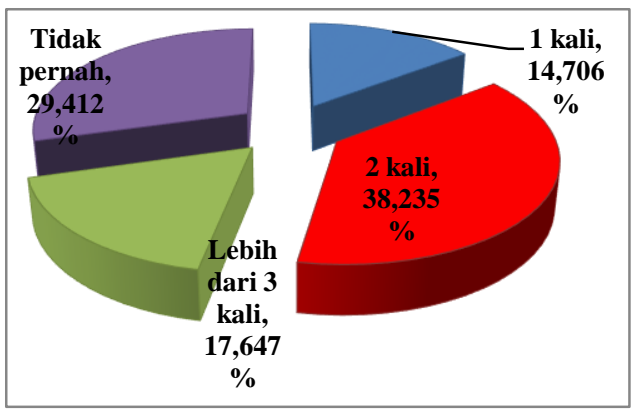

Gambar 4.32. Diagram Lingkaran Mahasiswa Tidak Mengikuti Perkuliahan di kelas M.K Studi Khusus Seni Lukis

Memilih karena rasa simpatik pada pengajar dan karena dorongan orang tua sebesar $0 \%$.

Kenyataan tersebut tentunya tidak sejalan dengan teori yang telah dikemukakan, yaitu bahwa mata kuliah studi khusus seni lukis yang dipilih mahasiswa diragukan kesesuaiannya dengan minatnya. Ternyata mahasiswa pada umumnya telah dapat menyatakan pilihannya secara realistis yaitu sesuai dengan minatnya. Ini berarti mereka telah menyadari pentingnya kesesuaian mata kuliah studi khusus seni lukis dengan minatnya sendiri.

Hasil belajar mahasiswa kelas A,B,C dan D angkatan 2014 mendapat nilai sangat bagus yaitu nilai A sebanyak 25 orang dari 34 mahasiswa dengan persentase sebesar 73,529\%, dan mahasiswa yang mendapat nilai bagus yaitu B sebanyak 6 orang dari 34 
mahasiswa dengan persentase sebesar 17,647\%. Namun 3 orang mahasiswa mendapat nilai $\mathrm{E}$ dengan nilai persentase sebesar $8,824 \%$, sehingga mahasiswa harus mengulang mata kuliah studi khusus seni lukis di semester berikutnya.

Berdasarkan penjelasan di atas, maka dapat disimpulkan bahwa minat yang tinggi akan memudahkan mahasiswa dalam pencapaian tujuan belajar yakni nilai/prestasi yang tinggi. Jadi, minat memang mempengaruhi nilai/prestasi belajar, minat yang tinggi akan menghasilkan prestasi yang tinggi dan minat yang rendah akan menghasilkan prestasi yang rendah.

\section{KESIMPULAN}

1. Dari keseluruhan mata kuliah studi khusus di jurusan seni rupa, peminat mata kuliah studi khusus seni lukis adalah tertinggi persentasenya dibanding dengan mata kuliah studi khusus lain. Hal tersebut terbukti dari hasil penelitian bahwa sebanyak 43,038\% memilih mata kuliah studi khusus seni lukis, sebesar 3,797\% memilih studi khusus seni patung, studi khusus seni kriya sebesar $13,924 \%$, sedangkan studi khusus seni grafis komputer sebesar $39,241 \%$, dan tidak ada satu pun mahasiswa memilih mata kuliah studi khusus fotografi.

2. Mahasiswa Jurusan Seni Rupa Fakultas Bahasa dan Seni
Universitas Negeri Medan Angkatan 2014 memilih Mata Kuliah Studi Khusus seni lukis didorong oleh faktor minatnya sendiri, sebanyak 97,059\% (33 orang), memilih karena rasa simpatik pada pengajar dan karena dorongan orang tua sebesar $0 \%$. Sedangkan memilih karena diajak teman berjumlah satu orang dengan persentase $2,941 \%$.

3. Hasil belajar mahasiswa mendapat nilai rata-rata bagus, mahasiswa yang mendapat nilai sangat bagus yaitu nilai A sebanyak 25 orang dari 34 mahasiswa dengan persentase sebesar 73,529\%, dan mahasiswa yang mendapat nilai bagus yaitu $B$ sebanyak 6 orang dari 34 mahasiswa dengan persentase sebesar $17,647 \%$. Namun 3 orang mahasiswa mendapat nilai $\mathrm{E}$ dengan nilai persentase sebesar $8,824 \%$, sehingga mahasiswa harus mengulang mata kuliah studi khusus seni lukis di semester berikutnya.

4. Minat berpengaruh pada nilai/prestasi belajar, minat yang tinggi akan menghasilkan prestasi yang tinggi dan minat yang rendah akan menghasilkan prestasi yang rendah.

\section{SARAN}

1. Pihak Jurusan perlu untuk berusaha mengadakan alat pengukur minat mahasiswa, sebelum mahasiswa memilih mata kuliah studi khusus untuk memastikan kesesuaian bakat 
dan minat yang dimiliki mahasiswa dengan mata kuliah studi khusus yang akan dipilihnya.

2. Minat belajar yang dimiliki mahasiswa sudah termasuk tinggi, namun dibutuhkan peningkatan minat dalam diri mahasiswa, terbukti masih ada mahasiswa yang belum mampu mempunyai kesadaran yang tinggi untuk belajar dan rasa ingin tahu yang rendah. Peningkatan minat mahasiswa dapat diupayakan melalui peningkatan pemahaman tentang pelajaran seni lukis secara mendalam.

3. Dosen pengajar perlu memberikan gaya-gaya belajar yang baru, menarik dan tidak monoton untuk menambah minat mahasiswa belajar seni lukis.

4. Jurusan Seni Rupa disarankan untuk melengkapi sarana dan prasarana studi khusus seni lukis agar dapat menunjang minat belajar melukis mahasiswa.

\section{DAFTAR RUJUKAN}

Buku Pedoman Universitas Negeri Medan . 2012. Medan : Universitas Negeri Medan.

Djaali, H. Psikologi Pendidikan. 2008. Jakarta: Bumi Aksara.

Ellsworth, Maud. 1957. Art For The High School. Chicago: University of Kansas.
Khairani, Makmun. 2013. Psikologi Belajar. Yogyakarta: Aswaja Pressindo.

Priyatno, Agus. 2012. Memahami Seni Rupa. Medan: Unimed Press. Universitas Negeri Medan.

Ross, Stephen David. Art And Its Significance. State University of New York Press, Albany.

Sembiring, Dermawan. 2014. Wawasan Seni. Medan: Unimed Press. Universitas Negeri Medan.

Slameto. 2010. Belajar dan FaktorFaktor yang Mempengaruhinya, Jakarta: Rineka Cipta

Sugati. 1988. Studi Penjurusan di SMA dan Kaitannya dengan Minat Siswa pada Siswa Kelas II SMA Negeri 4 Medan Tahun Ajaran 1987/1988. Ringkasan Thesis. Medan:Fakultas Ilmu Pendidikan. IKIP Medan.

Sugito dan Ibrahim, Anam. 2015. Metode Penelitian Pendidikan Seni Rupa. Jurusan Pendidikan Seni Rupa. Medan: Unimed.

Sugiyono,2010. Metode Penelitian Kuantitatif, Kualiratif dan $R \& D$. Bandung: Alfabeta. 
Triyanto. R. 2013. Apresiasi Seni Rupa

Semiotika Matahari dalam

Lukisan Affandi. Medan: Unimed

Press. Universitas Negeri Medan. 